\title{
Minimally Invasive Pediatric Cardiac Surgery is Here to Stay
}

\author{
Juan Miguel Gil Jaurena* \\ Chief Pediatric Cardiac Surgery, Hospital Gregorio Marañón, Spain
}

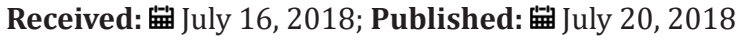

*Corresponding author: Juan-Miguel Gil Jaurena, Pediatric Cardiac Surgery, Hospital Gregorio Marañón, C/O’Donnell 50. 28009.

Madrid, Spain, Tel: 34650638004; Email: giljaurena@gmail.com

\section{Introduction}

Surgical closure of cardiac defects via a full mid-line sternotomy has been considered the gold standard for over 50 years. Due to the boom in interventional cardiology and the proliferation of techniques such as laparoscopy or thoracoscopy in other surgical specialties, several teams have adopted alternative approaches to median sternotomy [1-7]. The initial enthusiasm, fuelled by the technical advances of the past twenty-five years, stood against the reticence of those with a traditional approach. Doubts regarding the complexity and operative time of the technique, as well as its outcomes, prevented minimally invasive surgery from becoming widely used in congenital heart disease. Among the most frequent alternative approaches (Figure 1) we find: lower ministernotomy [8-11], right sub-mammary [1,12-16], postero-lateral thoracotomy $[17,18]$ and right axillary incisions [19-23]. Main advantages are cosmesis and earlier recovery, as well as saving blood products and lower infection rates.

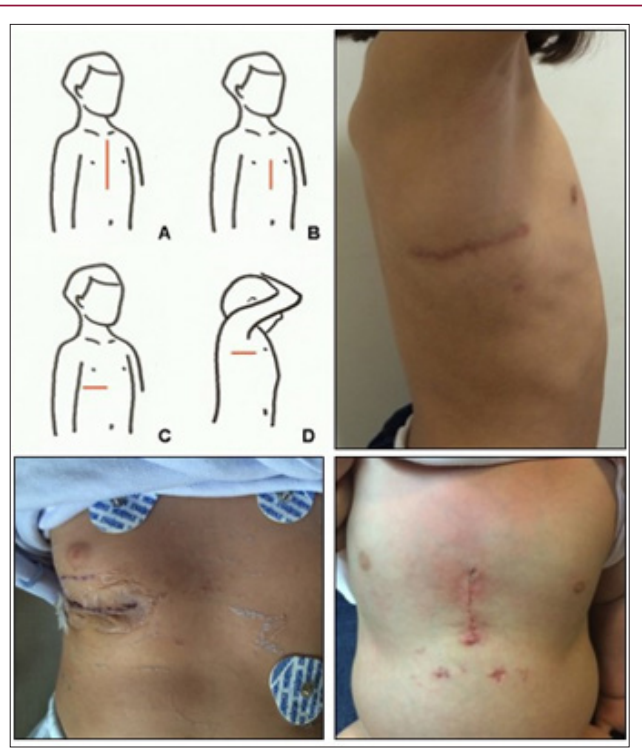

Figure 1: Clockwise from top left: drawing displaying several alternatives to midline sternotomy. Axillary approach, lower mini-sternotomy and sub-mammary incision.
On the other hand, a steep learning curve and technical difficulties in handling some steps (myocardial protection, deairing maneuvers, and so on) discourage many surgeons to include these minimally invasive procedures within their routine practice. Our group has been performing minimally-invasive congenital heart surgery for the last 20 years [24,25]. Sub-mammary incision in adolescent and young ladies was our first approach, which has evolved to a vast array of alternatives including several cardiac conditions since. Early in our experience, the rationale was to perform the whole procedure (full cannulation and cardiac repair) through an incision which could spare a complete median sternotomy. Then, lateral-posterior, axillary thoracotomy and lower partial sternotomies were sequentially added to our armamentarium (Figure 1). Interestingly, trends in adult surgery pushing forward less invasive techniques for valvular repair paved the way for its adoption in the congenital setting.

Thus, upper mini-sternotomy for aortic valve procedures and video-assisted anterior mini-thoracotomies for atrial septal defects (ASD), borrowed from mitral surgery, were implemented in our strategy (Figure 2). The latter means a shift in our early philosophy of single-different incision, since we have moved to a multi-smallaccess for peripheral cannulation plus additional ports. Needless to say that new tools such us shafted instruments, bendable sternal/ rib spreaders, soft tissue retractors, etc. ease that change. Special attention merits video-assisted facilities learnt from our thoracic colleagues. Arrhythmia surgery can be carried out, even in pediatric patients, only by thoracic ports (Figure 2) as we recently reported $[26,27]$. Currently, surgical approach depends on age/weight and cardiac condition. Small babies (eg, ventricular septal defects) are best approached by lower sternotomy wheres an ASD can be closed through the right axilla in a $15 \mathrm{Kg}$. child or, alternatively, by the submammary crease (with/without video-assistance) in an adolescent.

Tables $1 \& 2$ summarize our group data along the last five years. As experience is gathered, every patient is best suited according body-size and pathology as above mentioned [24,25]. Many groups have shifted towards the minimally invasive surgical approaches in pediatrics [1-7]. The rationale, beyond cosmesis, is offering the same 
results with new incisions, when catheter-based interventional procedures are also difficult or contra-indicated. Some teams are keen on a single particular approach, whereas others prefer to be familiar with many of them [4-6,24]. Whether this is a strategy or a matter of evolution is beyond the scope of this paper. Currently, the range of incisions different from a full mid-line sternotomy is rich enough to provide us many options. Interestingly, among the literature reviewed, some papers underline the steps to set up programs [25,28-30]. Particularly relevant is the publication by Bonaros et al. [31], in which the authors split every procedure in several parts and analyze them separately, so as to accurately depict anyone's learning curve.

Table 1: surgical minimally-invasive approaches.

\begin{tabular}{|c|c|}
\hline Approach & Number \\
\hline Sub-mammary & 35 \\
\hline Axillary & 40 \\
\hline Lateral-posterior & 11 \\
\hline Upper mini-sternotomy & 18 \\
\hline Lower mini-sternotomy & 141 \\
\hline Video-assisted mini-thoracotomy & 19 \\
\hline TOTAL & 264 \\
\hline
\end{tabular}

Table 2: cardiac conditions approached.

\begin{tabular}{|c|c|}
\hline Cardiac Conditions & Number \\
\hline $\begin{array}{c}\text { Ostium Secundum Atrial Septal } \\
\text { Defect (ASD) }\end{array}$ & 94 \\
\hline Sinus Venosus ASD & 23 \\
\hline Ventricular Septal Defect (VSD) & 77 \\
\hline $\begin{array}{c}\text { Ostium Primum ASD (Partial AV } \\
\text { septal defect) }\end{array}$ & 22 \\
\hline $\begin{array}{c}\text { Complete atrio-ventricular septal } \\
\text { defect }\end{array}$ & 8 \\
\hline Aortic valve stenosis/regurgitation & 17 \\
\hline Others & 23 \\
\hline TOTAL & 264 \\
\hline
\end{tabular}

The take-home message in a minimally invasive program is trying to convert any patient (when needed) to another minimally invasive approach in an expeditious way, for the sake of safety. Obviously, a partial sternotomy (either upper or lower one) can be easily enlarged to a full sternotomy. An axillary incision can be converted to a postero-lateral one (again, minimally invasive) by just prolonging posteriorly the already drawn surgical mark and severing the latissimus dorsi muscle [32]. The new program of video-assisted mini-thoracotomy is growing-up under the readiness to convert incisions to a full sub-mammary one, if needed. When approaching the chest thoracoscopically, the ports are fashioned in such a way that an axillary or sub-mammary incision can be produced, if requested (Figure 2, bottom pictures).
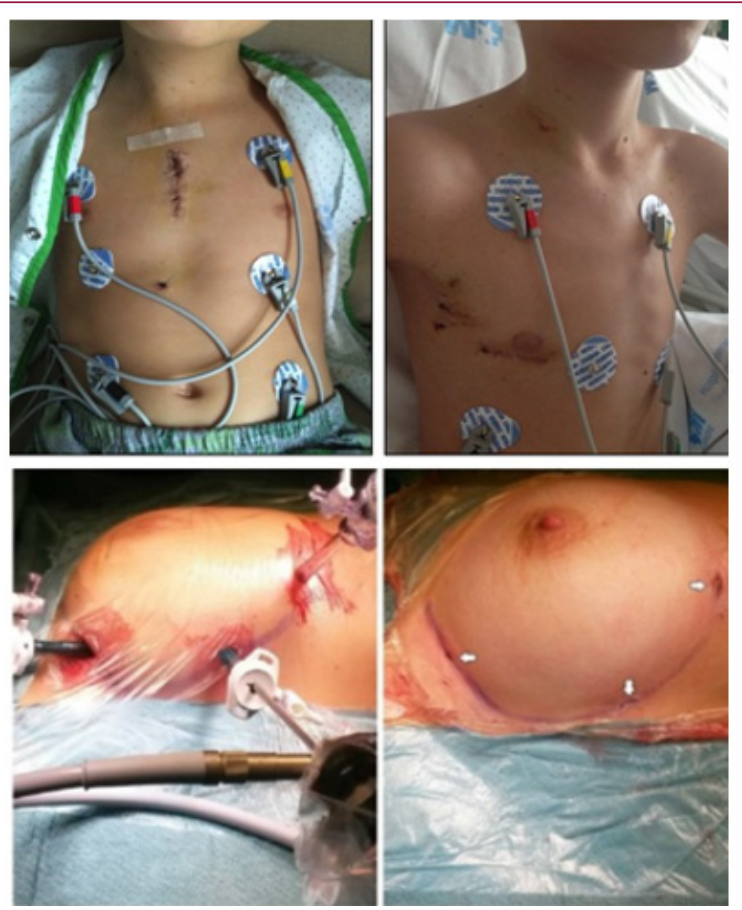

Figure 2: Top left: upper mini-sternotomy (aortic valve procedure). Top right: video-assisted $4 \mathrm{~cm}$. minithoracotomy, with two additional $10 \mathrm{~mm}$. ports under the right arm (ASD closure). Bottom: Thoracoscopic ablation with three ports along the sub-mammary crease.

After gathering some experience, the question is how to move forward with the program? There is no clear answer, since not all surgeons in the same Institution are at the same level of proficiency or are still in their learning curve. Thinking in terms of contraindications rather than indications, as a last step of training, could be a reasonable marker. In other words, we are not expecting for the "perfect patient" to come and be an ideal candidate for a minimally invasive approach. We rather think about the contraindications, if any, for a minimally invasive procedure in every patient. Minimally invasive pediatric cardiac surgery is currently becoming a routine practice in many centers worldwide. The different approaches need their own learning curve, either straightforward or a steep one.

Our recent experience [25] demonstrates that a comprehensive schedule allows a safe and custom-made approach to train new surgeons in the field and enhances enthusiasm in developing further strategies on their own. A record of conversion-rate and complications should be used as marker of performance and quality standard. The new adopters can take their own training pace according to their level and skills. Interestingly, the wider the offer of approaches, the more ideas come up for new alternative minimally invasive methods. Maybe the future will rely on totally robotic or endoscopic [33-37] surgery but, for the time being, offering alternative approaches is worth trying.

\section{References}

1. Lancaster LL, Mavroudis C, Rees AH, Slater AD, Ganzel BL, et al. (1990) Surgical approach to atrial septal defect in the female. Right thoracotomy versus sternotomy. Am Surg 56(4): 218-221. 
2. Cremer JT, Boning A, Anssar MB, Kim PY, Pethig K, et al. (1999) Different approaches for minimally invasive closure of atrial septal defects. Ann Thorac Surg 67(6): 1648-1652.

3. Hagl C, Stock U, Haverich A, Steinhoff G (2001) Evaluation of different minimally invasive techniques in pediatric cardiac surgery: is a full sternotomy always a necessity. Chest 119(2): 622-627.

4. Del Nido PJ (2007) Minimal incision congenital heart surgery. Semin Thorac Cardiovasc Surg 19(4): 319-324.

5. Vida VL, Padalino MA, Motta R, Stellin G (2011) Minimally invasive surgical options in pediatric heart surgery. Expert Rev Cardiovasc Ther 9(6): 763-769.

6. Gil-Jaurena JM, Zabala JI (2013) Cirugía cardiaca mínimamente invasiva en el niño. Cardiocore 48: 17-20.

7. Luo H, Wang J, Qiao C, Zhang X, Zhang W, et al. (2014) Evaluation of different minimally invasive techniques in the surgical treatment of atrial septal defect. J Thorac Cardiovasc Surg 148(1): 188-193.

8. Bichell DP, Geva T, Bacha EA, Mayer JE, Jonas RA, et al. (2000) Minimal access approach for the repair of atrial septal defect: the initial 135 patients. Ann Thorac Surg 70(1): 115-118.

9. Nicholson IA, Bichell DP, Bacha EA, del Nido PJ (2001) Minimal sternotomy approach for congenital heart operations. Ann Thorac Surg 71(2): 469-472.

10. Sun HS, Ma WG, Xu JP, Sun LZ, Lu F, et al. (2006) Minimal access heart surgery via lower ministernotomy: experience in 460 cases. Asian Cardiovasc Thorac Ann 14(2): 109-1013.

11. Bautista-Hernández V (2014) Cirugía de mínima invasión. Cir Cardiov. 21: $107-110$.

12. De Mulder W, Vanermen H (2002) Repair of atrial septal defects via limited right anterolateral thoracotomy. Acta Chir Belg 102(6): 450-454.

13. Dabritz S, Sachweh J, Walter M, Messmer BJ (1999) Closure of atrial septal defects via a limited right anterolateral thoracotomy as a minimal invasive approach in female patients. Eur J Cardiothor Surg 15(1): 18-23.

14. Mishaly D, Ghosh P, Preisman S (2008) Minimally invasive congen- ital cardiac surgery through right anterior minithoracotomy approach. Ann Thorac Surg 85(3): 831-835.

15. Massetti M, Babatasi G, Rossi A, Neri E, Bhoyroo S, et al. (1996) Operation for atrial septal defect through a right antero- lateral thoracotomy: current outcome. Ann Thorac Surg 62(4): 1100-1103.

16. Gil-Jaurena JM, Murtra M, Gon calves A, Miró L, Vilá R, García- Górriz M (2002) Estudio comparativo de la vía de abordaje en el cierre de la comunicación interauricular. Rev Esp Cardiol 55(11): 1213-1216.

17. Metras D, Kreitmann B (1999) Correction of cardiac defects through a right thoracotomy in children. J Thorac Cardiovasc Surg 117(5): 10401042 .

18. Vida VL, Padalino MA, Bhattarai A, Stellin G (2011) Right posteriorlateral minithoracotomy access for treating congenital heart disease. Ann Thorac Surg 92(6): 2278-2280.

19. Yang X, Wang D, Wu Q (2001) Repair of atrial septal defect through a minimal right vertical infraaxillary thoracotomy in a beating heart. Ann Thorac Surg 71(6): 2053-2062.

20. Schreiber C, Bleiziffer S, Kostolny M, Hörer J, Eicken A, et al. (2005) Minimally invasive midaxillary muscle sparing thoraco- tomy for atrial septal defect closure in prepubescent patients. Ann Thorac Surg 80(2): 673-676.

21. Prêtre R, Kadner A, Dave H, Dodge-Khatami A, Bettex D, et al. (2005) Right axillary incision: a cosmetically superior approach to repair a wide range of congenital cardiac defects. J Thorac Cardiovasc Surg 130(2): 277-281.
22. Gil-Jaurena JM, Zabala JI, Conejo L, Cuenca V, Picazo B, Jiménez C, et al. (2011) Cirugía mínimamente invasiva en niños. Corrección de la comunicación interauricular por vía axilar y submamaria. Rev Esp Cardiol 64(3): 208-212.

23. Gil-Jaurena JM, Castillo R, Zabala JI, Conejo L, Cuenca V, et al. (2013) Incisión axilar para el cierre quirúrgico de la comunicación interauricular. An Pediatr 79(2): 108-111.

24. Gil-Jaurena JM, González-López MT, Pérez-Caballero R, Pita A, Castillo R, et al. (2016) 15 years of minimally invasive paediatric cardiac surgery; development and trends. An Pediatr 84(6): 304-310.

25. Gil-Jaurena JM, Pérez-Caballero R, Pita-Fernández A, González-López MT, Sánchez J, et al. (2016) How to set-up a program of minimally-invasive surgery for congenital heart defects. Transl Pediatr 5(3): 125-123.

26. Pérez-Caballero R, Pita A, González-López MT, De Agustín, JC, Gil-Jaurena JM (2016) Combined Ablation and Exclusion of the Left Atrial Appendage in a Pediatric Patient: A Minimally Invasive Simplified Approach. Ann Thorac Surg 101(6): 2379-2382.

27. Roy I, Álvarez V, Ormaetxe JM, Martínez-Alday JD, Pérez-Caballero R, GilJaurena JM (2017) Wolff-Parkinson-White Syndrome Associated With a Fistula Between the Right Atrial Appendage and Right Ventricle. Rev Esp Cardiol 70(10): 876-888.

28. Dietl CA, Torres AR, Favaloro RG (1992) Right submammarian thoracotomy in female patients withatrial septaldefects and anomalous pulmonary venous connections. Comparison between the transpectoral and subpectoral approach. J Thorac Cardiovasc Surg 104(3): 723-727.

29. Bleiziffer S, Schreiber C, Burgkart R, Regenfelder F, Kostolny M, Libera P, et al. (2004) The influence of right anterolateral thoracotomy in prepubescent female patients on late breast development and on the incidence of scoliosis. J Thorac Cardiovasc Surg 127(5): 1474-1480.

30. Vida VL, Tessari C, Fabozzo A, Padalino MA, Barzon E, et al. (2013) The evolution of the right anterolateral thoracotomy technique for correction of atrial septal defects: cosmetic and functional results in prepubescent patients. Ann Thorac Surg 95(1): 242-248.

31. Bonaros N, Schachner T, Oehlinger A, Ruetzler E, Kolbitsch C, et al. (2006) Robotically assisted totally endoscopic atrial septal defect repair: insights from operative times, learn- ing curves, and clinical outcome. Ann Thorac Surg 82(2): 687-693.

32. Gil-Jaurena JM, Castillo R, González M (2013) Complete muscle- sparing technique in axillary closure of atrial septal defects. Asian J Cardiothorac Surg 21(6): 756-758.

33. Ma ZS, Dong MF, Yin QY, Feng ZY, Wang LX (2011) Totally thoracoscopic repair of atrial septal defect without robotic assistance: a single-center experience. J Thorac Cardiovasc Surg 141(6): 1380-1383.

34. Wang F, Li M, Xu X, Yu S, Cheng Z, et al. (2011) Totally thoracoscopic surgical closure of atrial septal defect in small children. Ann Thorac Surg 92(1): 200-203.

35. Liu G, Qiao Y, Ma L, Ni L, Zeng S, et al. (2013) Totally thoracoscopic surgery for the treatment of atrial septal defect without of the robotic Da Vinci surgical system. J Cardiothorac Surg 8: 119-122.

36. Rotes AS, Burkhart HM, Suri RM, Grogan M, Taggart NW, et al. (2014) Minimally invasive video-assisted surgical closure of atrial septal defects: a safe approach. World J Pediatr Congenit Heart Surg 5(4): 527533.

37. Zhe Z, Kun H, Xuezeng X, Yunge C, Zengshan M, et al. (2014) Totally thoracoscopic versus open surgery for closure of atrial septal defect: propensity-score matched comparison. Heart Surg Forum17(4): E227-E231. 
ISSN: 2574-1241

DOI: 10.26717/BJSTR.2018.07.001455

Juan Miguel Gil Jaurena. Biomed J Sci \& Tech Res

(C) (i) This work is licensed under Creative

Submission Link: https://biomedres.us/submit-manuscript.php

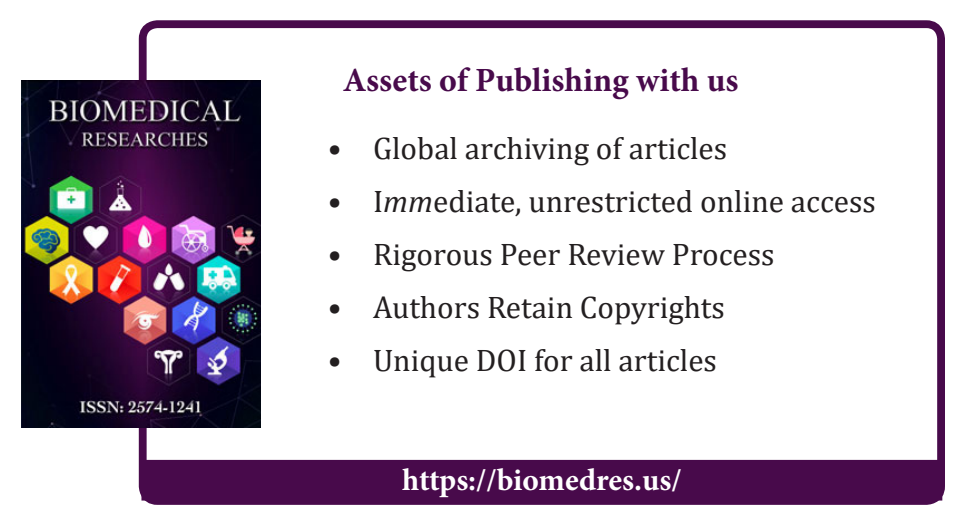

